\title{
PCR-Based Assay for Detection of Harpophora maydis the Causal Agent of Late Wilt Disease in Maize Plant Parts
}

\section{El-Naggar, A.A.A.}

Maize and Sugar Crops Diseases Research Department, Plant Pathology Research Institute, Agricultural Research Center, Giza, Egypt.

Importance of maize late wilt caused by Harpophora maydis 1 (Cephalosporium maydis Smra, Sabet \& Hingorani) comes from the sudden and relatively rapid wilt of maize plants at the time of flowering and until shortly before maturity. So, the detection of the causal agent early before symptoms appearance may be useful for managing the disease. For this purpose, two maize plants were chosen randomly at $7,21,35,49,63,77,91$ and 105 days after seeding in greenhouse and field infested soils, during 2016 and 2017 seasons. Fungal DNA was detected in emerged plant parts using the specific primer of $H$. maydis. The first detection of the fungal DNA was at $7 \mathrm{~d}$ after seeding in roots and leaves of greenhouse and field seedlings. At the age of $21,35,49,63$ days the fungus was detected in all tested plant parts. With pathogen progression, from $77 \mathrm{~d}$ to $105 \mathrm{~d}$ after sowing, clear amplified fungal DNA was found in samples taken from stalk-internodes, tassels, ear-shanks, cobs, kernels and leaves with the consistent of disease symptoms. But the unique band of $H$. maydis did not appear in the amplified DNA taken from mature kernels at the age of 105 days. As a conclusion of the obtained results, it is clearly pronounced that $H$. maydis colonized all maize plant parts emerged during the growing season. Also, polymerase chain reaction (PCR)based assay was successfully employed to identify $H$. maydis directly from the mycelia that embedded in maize plant tissues, with no need to obtain pure fungal cultures for detection compared with traditional method. Thus, this protocol can be used for diagnosis of infected plants by late wilt causal agent.

Keywords: PCR-based assay, Harpophora maydis, Cephalosporium maydis, detection, specific primer, Maize, Late wilt.

Harpophora maydis Gams (Synonym Cephalosporium maydis Samra, Sabet \& Hingorani), is one of the most important soilborne and seedborne fungi (El-shafey et al., 1991 and Michail et al., 1999), attacks maize in Egypt causing late wilt. The disease acts as a principle limiting factor in maize production. It was first reported in Egypt in 1960 and the causal organism was identified as Cephalosporium maydis (Samra et al., 1962 and 1963). C. maydis renamed by Gams (2000) as H. maydis, hence Harpophora spp are characterized by fast-growing, thin colonies with sickleshaped conidia. As well as older hyphae are heavily pigmented, younger hyphae are 
nearly hyaline, and phialides are intermediate in pigmentation relative to the younger hyphae. H. maydis reproduces asexually, and no perfect state has been identified (Saleh and Leslie, 2004). Infection of maize occurs through the roots or mesocotyl (Sabet et al., 1970a). The fungus grows superficially on the roots, producing hyphae with short, thick-walled, swollen cells. After penetration, the fungus colonizes xylem tissue at 21 days after sowing and rapidly translocated to the upper parts of the plant. When infections are severe, the fungus colonizes the kernels, resulting in seed-borne dissemination and also causes seed rot and damping off (El-Shafey and Claflin, 1999; Michail et al., 1999 and Payak et al., 1970). The most common character distinguished late wilt disease is relatively rapid wilting of maize plants appeared at flowering stage and until shortly before maturity. The wilting progresses from the lower to the upper portions of the plant. Leaves become dull green, eventually lose color and become dry. Vascular bundles in the stalk become reddish brown, lower internodes shrunken and dry (Samra et al., 1963; ElShafey and Claflin, 1999). The geographic distribution of the disease is expanded; India (Payak et al., 1970), Portgal and Spain (Molinero-Ruiz et al., 2011), Italy and Hungary (Pecsi and Nemeth, 1998) and Israel (Drori et al., 2013). In addition, latent infection of the causal organism is existed (El-Naggar and Sabry, 2011 and Drori et al., 2013). Seed quantity is negatively correlated to disease severity (El-naggar $e t$ al., 2015). Yield losses of up to $52 \%$ have been reported (El-Naggar et al., 2015). The degree of losses depends on the reaction of cultivated varieties and the time of symptoms appearance (El-Shehawy et al., 2014; El-Naggar et al., 2015 and Johal et al., 2004). During the last decades, the use of molecular markers based on the polymerase chain reaction (PCR) for species identification and as a diagnostic tool became very popular (Nicholson et al., 1996; Murillo et al., 1998; Moller et al., 1999; Drori et al., 2013 and Degani and Cernica, 2014). H. maydis specific oligonucleotides were designed and used as primers for in vitro DNA amplification by the polymerase chain reaction (Saleh and Leslie, 2004). Recently, Drori et al. (2013) modified the primer and produced a new sequence ( $200 \mathrm{bP}$ ) which is a major part of a larger AFLP fragment that was previously proved to be species-specific (Saleh and Leslie, 2004). Drori et al. (2013) seeded two sweet corn cultivars (susceptible and partial resistant to late wilt) in H. maydis infested field for assessing resistance of maize varieties and fungus molecular diagnosis. They arbitrary selected plants at the age of 22-78 days with approximately 7 days intervals for DNA isolation from roots, stems, leaves and kernels. They found that the first detection of the fungus was in the age of 43 days in roots and stems and at $78 \mathrm{~d}$ in kernels at eating stage. The authors used a narrow period (78 days) out of long maize growing season (approximately 120 days) and also selected portions of some not all plant parts in their studies. So, we need more details about the movement or development of $H$. maydis in maize plant parts during the growing period. The aim of this study is to answer the question of; in which maize plant parts $H$. maydis colonizes during greenhouse and field growing season using polymerase chain reaction (PCR)-based

Egypt. J. Phytopathol., Vol. 47, No. 1 (2019) 
assay with its unique primer?. This may help to apply any possible treatment to reduce disease appearance especially at early stages of plant age.

\section{Materials and Methods}

Harpophora maydis isolates:

Five single spore cultures of $H$. maydis were used in this study. The isolates were recovered from wilting plants obtained from Gharbia (Hm-1), Kafr El Sheikh (Hm2), Beheira (Hm-3), Beni Sweif (Hm-4) and Minia (Hm-5) governorates maize fields. All isolates were previously identified as $H$. maydis depending on cultural and microscopic characteristics (Samra et al., 1963). Herein, we used the modified unique oligonucleotides primer for H. maydis diagnosis (Drori et al., 2013) as the molecular diagnostic tool to satisfy the previous identification.

\section{Inoculum preparation:}

A clean grain sorghum seeds $(100 \mathrm{~g})$ were soaked in water overnight in $500 \mathrm{ml}$ glucose glass bottle, and then the excess water was decanted and autoclaved for 1 hour. One piece, $2 \mathrm{~cm}^{2}$, from 7-d-old H. maydis culture (grown on PDA $+0.2 \%$ yeast extract at $27^{\circ} \mathrm{C}$ ) was transferred to each bottle and incubated at room temperature $\left(27^{\circ} \mathrm{C} \pm 2\right)$ for 15 days and afterward the bottles were used for soil infestation of greenhouse experiments (Sabet et al., 1966; El-Shabrawy and Shehata, 2018; El-Gazzar et al., 2018).

Maize hybrids screening for susceptibility to late wilt:

Thirteen maize hybrids (Table 1) were cultivated for testing their reaction against H. maydis to select the susceptible one for further studies. The tested hybrids were obtained from Agricultural research Center, Maize Research Department (ARCMRD); HYTECH and PIONEER companies. For soil infestation, H. maydis colonized sorghum seeds of each of the five selected isolates was mixed with equal quantity. Eventually, $200 \mathrm{~g}$ of the mixture were added to the loam soil of $10 \mathrm{Kg}$ capacity pots $(35 \mathrm{~cm}$ in diam.) and mixed (4 pots/ hybrid). Seeds were planted on May 5, 2015 at $2 \mathrm{~cm}$ depth, eight seeds per pot. Five maize plants were left in each pot after 15 days of seedling emergence. All cultural practices were done as recommended. The experiment was carried out in a completely randomized design. Disease reaction was recorded as a percent of infection after 90 days from seeding date. Data were analyzed by ANOVA using Duncan's multiple range test with significant level 5\% after transformed to Arcsine. ANOVA was performed using COSTAT version 3.03 software (Steel and Torrie, 1980).

Molecular detection of H. maydis:

According to the results of the previous experiment, Maize hybrids screening for susceptibility to late wilt, the susceptible hybrid Pioneer SC 3062 was chosen for greenhouse and field assay. 
Greenhouse experiments:

Five seeds of the susceptible hybrid SC3062 were seeded (May 24, 2016) in infested soil of pots $(35 \mathrm{~cm}$ in diam.), as mentioned before for soil infestation. Two plants were randomly sampled from the age of 7 to 91 days with $15 \mathrm{~d}$ intervals. Plants were divided according to their emerged principal parts, i.e. roots, stalk-internodes, leaves, ear-shank, cob, kernels and tassel. The stalk internodes of each plant were separated individually and numbered, i.e. stalk-internode number $1,2 \ldots$ etc. Portion (2-3 cm long) of each plant part was wrapped in aluminum foil stripes, labeled and immediately stored at $-20^{\circ} \mathrm{C}$ until further use for DNA extraction. The experiment was repeated as it is on May 29, 2017. All cultural practices were done as recommended.

Field experiment:

Seeds of the susceptible hybrid Pioneer SC 3062 were seeded on May 14, 2016 in late wilt nursery field (Giza Agricultural Research Station, ARC, Egypt). The experiment was carried out in a randomized complete block design with three replicates. Each replicate comprised of 6 rows, $4 \mathrm{~m}$ long and $70 \mathrm{~cm}$ apart with $20 \mathrm{~cm}$ plant distance. Rows were infested by adding $600 \mathrm{~g}$ of $\mathrm{H}$. maydis colonized sorghum seeds (prepared as described before) into a groove, $3 \mathrm{~cm}$ depth and $5 \mathrm{~cm}$ width, made in each row. Afterward two seeds were planted and covered with soil and irrigated. All cultural practices were done as recommended. Two plants were randomly sampled at the age of 7, 21, 35, 49, 63, 77, 91 and 105 days after planting. Then, each plant was divided separately according to their emerged principal parts as mentioned before in the greenhouse. Samples of 5-10 kernels from the selected plants were used. All samples were wrapped in aluminum foil stripes, labeled and immediately stored at $-20^{\circ} \mathrm{C}$ until further DNA extraction.

Fungal culture:

Fungal culture (Hm-4 isolate) was grown in potato dextrose broth (PDB) (Murillo et al., 1998) supplemented with $0.2 \%$ yeast extract (Sabet et al., 1966) and incubated at $27^{\circ} \mathrm{C}$ for 7 days. After that, the mycelium was harvested, rinsed thoroughly with sterile distilled water, dried using filter paper (No. 102) and stored at $-20^{\circ} \mathrm{C}$ until used.

DNA extraction from fungal culture and maize plant parts:

To extract DNA from $H$. maydis culture and maize plant parts possibly infected by the fungus, frozen samples were ground to a fine powder by liquid nitrogen using mortar and pestle. Afterward, $0.5 \mathrm{~g}$ of each ground sample immediately was stored at $-20^{\circ} \mathrm{C}$ in separate micro-centrifuge tubes $(1.5 \mathrm{~mL})$ until used. A modified CTAB method of Allen et al. (2006) for DNA extraction was used with a slight modification. Briefly, $1 \mathrm{ml}$ of preheated $\left(65^{\circ} \mathrm{C}\right.$ for $1-2 \mathrm{hr}$ in water bath, KOTTERMANN - Germany) extraction buffer (100mM Tris-HCL, pH 8; $20 \mathrm{mM}$ EDTA, pH 8; $1.4 \mathrm{M} \mathrm{NaCL} ; 2 \% \mathrm{CTAB}$, (W/V) and $1 \%$ beta-mercaptoethanol) was added to each tube, vortexed thoroughly for $5-10 \mathrm{~s}$ and incubated at $65^{\circ} \mathrm{C}$ for $30 \mathrm{~min}$

Egypt. J. Phytopathol., Vol. 47, No. 1 (2019) 
with inverting the tubes every 5-10 min. After centrifugation (Sigma 1-14) at 12,000 rpm for 5-10 min, the supernatant was transferred into new $2 \mathrm{ml}$ microfuge tube then $800 \mu \mathrm{l}$ of chloroform: isoamyl alcohol $(24: 1 \mathrm{v} / \mathrm{v})$ were added with mixing 2-3 min. The mixture was centrifuged again $(12,000 \mathrm{rpm}$ for $5 \mathrm{~min})$. Afterward, the upper phase was transferred to a fresh, sterile microfuge tube and mixed gently through inversion with $800 \mu \mathrm{l}$ of phenol: chloroform: isoamyl alcohol (25: 24: 1) at room temperature (RT) for $20 \mathrm{~min}$. Centrifugation was at $12,000 \mathrm{rpm}$ for $5 \mathrm{~min}$ at RT thereafter the upper layer was carefully transferred to new 2-ml microfuge tube. A pre-cooled isopropanol (stored at $-20^{\circ} \mathrm{C}$ ), $800 \mu \mathrm{l}$, were added then mixed by inverting the tubes and incubated at RT for $20 \mathrm{~min}$ to precipitate the DNA. The supernatant was removed after centrifugation at 10,000 rpm for $5 \mathrm{~min}$ at RT and then the pellet was re-suspended in $500 \mu \mathrm{TE}$ buffer (10mM Tris-HCL, PH 8.0, $1 \mathrm{mM}$ EDTA). A volume of $1 \mu \mathrm{l}$ of RNase A $(10 \mathrm{mg} / \mathrm{ml})$ was added into the sample mixture and then incubated at $37^{\circ} \mathrm{C}$ for $30 \mathrm{~min}$. Next, $25 \mathrm{ul}$ of $3 \mathrm{M}$ Sodium acetate $(\mathrm{NaAc})$ were added and mixed, afterward $600 \mu \mathrm{l}$ of pre-cooled absolute ethanol ($20^{\circ} \mathrm{C}$ ) were added, mixed, then the tubes were incubated at $-20^{\circ} \mathrm{C}$ for $20 \mathrm{~min}$. The mixture was centrifuged at $10,000 \mathrm{rpm}$ for $5 \mathrm{~min}$ and the supernatant was carefully decanted. DNA pellet was washed by adding $500 \mu \mathrm{l}$ of cold $\left(-20^{\circ} \mathrm{C}\right) 70 \%(\mathrm{v} / \mathrm{v})$ ethanol, dislodged by quick 1-2 s vortexing and the ethanol was removed after centrifugation at 10,000 rpm for $5 \mathrm{~min}$ at RT. DNA pellet was dried at RT under laminar flow to remove the residual ethanol then DNA was dissolved in $50 \mu 1$ of TE buffer at $4^{\circ} \mathrm{C}$. After the DNA was completely dissolved the microfuge tubes were stored at $-20^{\circ} \mathrm{C}$ until used.

Polymerase chain reaction $(P C R)$ :

PCR reaction was carried out in a thermal cycler (AB Applied Biosystems, 2720 - Singapore) in a volume of $25 \mu \mathrm{l}: 2 \mu \mathrm{l}$ primers $(20 \mu \mathrm{M}$ of each primer; A200a, Forward primer: 5'-CCGACGCCTAAAATACAGGA-3'; A200b, Reverse primer: 5'-GGGCTTTTTAGGGCCTTTTT-3'), $12.5 \mu 1$ of ready-to-PCR reaction mixture (OnePCRTM , GeneDirex), 1 or $2.5 \mu$ l DNA sample and 9.5 or $8 \mu 1$ sterile distilled water (SDW) for fungal and plant samples respectively. A program of one cycle $\left(94^{\circ} \mathrm{C}\right.$ for $\left.2 \mathrm{~min}\right)$ followed by 35 cycles $\left(94^{\circ} \mathrm{C}\right.$ for $30 \mathrm{~s}, 55^{\circ} \mathrm{C}$ for $30 \mathrm{~s}, 72^{\circ} \mathrm{C}$ for 1 $\mathrm{min}$ ) and a final step of $72^{\circ} \mathrm{C}$ for $5 \mathrm{~min}$ was performed (Drori et al., 2013). Aliquots of $50 \%$ of the PCR product mixture were analyzed on $1.4 \%$ agarose mediumgels (SCIE-PLAS) in TE buffer (10mM Tris-HCL, PH 8.0, 1mM EDTA), containing 0.5 $\mu \mathrm{g} / \mathrm{ml}$ ethidium bromide. After electrophoresis ( $90 \mathrm{~V}$ for $1.5 \mathrm{~h}$ ), a $200-\mathrm{bP}$ amplified DNA band (Drori et al., 2013) was identified under UV transilluminator (HerolabUVT-40 S/L) in comparison with 100bp DNA ladder (Thermo Scientific, GeneRuler 100bp plus DNA Ladder or 100 bp DNA Ladder, Solis BioDyne) and was photographed by digital still Camera (Sony, Cyber-Shot DSC-W510).

Recovery of H. maydis on PDA:

The same plant parts used for molecular detection of H. maydis were used for selecting segments to recovery the fungus on potato dextrose agar (PDA) medium 
(Table 2). Selected segments were sterilized in $70 \%$ ethyl alcohol, flamed and split or cut in cross sections with sterile scalpel; small pieces of tissues (5 pieces / plate) were placed on PDA supplemented by $0.2 \%$ yeast extract. $H$. mydis appearance was recorded after 7 days of incubation at $27^{\circ} \mathrm{C}$, and then was compared visually and microscopically with the previously identified isolates.

\section{Results}

Isolates identification using H. maydis-specific primer:

The 200bp unique band of $H$. maydis was identified with the amplified DNA of the selected five isolates, $\mathrm{Hm}-1, \mathrm{Hm}-2, \mathrm{Hm}-3, \mathrm{Hm}-4$ and $\mathrm{Hm}-5$, used in this study (Fig. 1).

Reaction of thirteen maize hybrids against late wilt:

Data in Table (1) reveal that the tested hybrids showed different reactions to late wilt since the infection ranged from 14.9 to $81.1 \%$. The hybrid HYTIC SC 2066 exhibited low degree of infection (14.9\%) followed by the hybrids HYTIC SC2055, PIONEER SC30N11 and PIONEER SC30K08 (21.4, 21.4 and $24.1 \%$, respectively). On the other hand, the hybrid PIONEER SC3062 showed high degree of susceptibility $(81.1 \%)$. so, it was selected for further greenhouse and field investigations. Meanwhile, other hybrids were also susceptible (the infection ranged from 26.6 to $60 \%$ ).

Table (1): Disease infection (\%) of 13 tested maize hybrids against late wilt under greenhouse conditions, 2015.

\begin{tabular}{lc}
\hline \multicolumn{1}{c}{ Tested hybrids } & $\%$ infection \\
\hline ARC-MRD-SC 162 & $60 \mathrm{~b}^{*}$ \\
ARC-MRD-SC173 & $33.2 \mathrm{de}$ \\
ARC-MRD-SC168 & $63.4 \mathrm{~b}$ \\
ARC-MRD-SC130 & $50.8 \mathrm{c}$ \\
ARC-MRD-SC131 & $35 \mathrm{~d}$ \\
ARC-MRD-SC122 & $43.1 \mathrm{c}$ \\
HYTECH-SC2066 & $14.9 \mathrm{~g}$ \\
HYTECH -SC2031 & $26.6 \mathrm{ef}$ \\
PIONEER-SC3062 & $81.1 \mathrm{a}$ \\
PIONEER-SC30K09 & $50.8 \mathrm{c}$ \\
HYTECH -SC2055 & $21.4 \mathrm{fg}$ \\
PIONEER-SC30K08 & $24.1 \mathrm{f}$ \\
PIONEER-SC30N11 & $21.4 \mathrm{fg}$ \\
\hline
\end{tabular}

*= Means followed by the same letter are not significantly different at $5 \%$ level.

Egypt. J. Phytopathol., Vol. 47, No. 1 (2019) 
Detection of H. maydis DNA in emerged maize plant parts:

To detect $H$. maydis in emerged maize plant parts; roots, stalk-internodes, tassels, cobs, ear-shanks, kernels and leaves during plant development, two greenhouse and one field experiments were conducted in Giza Agricultural Research Station, ARC, Egypt during 2016 and 2017. The sampling program included the susceptible hybrid, PIONEER SC3062, samples were taken from the age of $7 \mathrm{~d}$ to $91 \mathrm{~d}$ in the greenhouse and from $7 \mathrm{~d}$ to $105 \mathrm{~d}$ in the field with 15 days intervals. In 2016-greenhouse trail, a unique band (200-bP) of $H$. maydis DNA was detected in roots and leaves of $7 \mathrm{~d}$ old seedlings (Figs. 2 and 6A). After $21 \mathrm{~d}$ and $35 \mathrm{~d}$ of seeding, the pathogen DNA was detected also in roots, stalk-internode no. 1 and in leaves (Figs. 2 and 6A). In addition, a clear 200-bp band was visualized in all tested DNA samples of roots, leaves and stalk-internodes until number 5, 7 and 10 at the age of 49, 63 and 77 days, respectively (Figs. 2 and 6A). Eventually, after $91 \mathrm{~d}$ after sowing the causal agent colonized all tested samples of stalk-internodes, leaves, ears (cobs with initial kernels) and tassels since the 200-bp DNA band was appeared (Figs. 2 and 6).

On the other hand, in 2017-greenhouse experiment, the first detection of $H$. maydis distinguishing band (200-bp) was in roots and leaves samples of $7 \mathrm{~d}$ old seedlings (Figs. 3 and 6B). At the age of 21, 35, 49 and 63 days, the fungus progressed consistently with the emerged plant parts since the pathogen DNA was detected in roots, stalk-internodes and leaves. Also, at the age of 77 days fungal DNA was detected in the tested samples with the exception of roots and tassels. Finally, except of kernel's sample, a clear 200bp band was detected in roots, stalkinternodes, cob and tassel samples taken after 91 days from sowing.

In respect of $H$. maydis detection in 2016-field trail, a 200-bp amplified DNA band was identified in 7d old seedling roots and leaves (Figs. 4 \& 6C). Also, $H$. maydis unique band was detected in DNA of roots, stalk-internodes and leaves taken from 21, 35 and 49d old plants (Figs. 4 \& 6C). In addition, at the age of 63 days, a clear 200-bp band was appeared in stalk-internodes until no. 9, tassels, leaves, earshanks and ears (cobs with initial kernels) (Figs. 4 \& 6C). Moreover, at 77 and $91 \mathrm{~d}$ after sowing the causal fungus was distributed in all emerged plant parts and colonized roots, leaves, stalk-internodes, tassels, cobs and kernels which reflected by a clear 200-bp DNA band appearance (Figs. 4, 5 \& 6C). Later, in samples taken from $105 \mathrm{~d}$ old plants, the unique H. maydis DNA band was found in stalkinternodes until no. 11, leaves, tassels and cobs but was not detected in kernel's sample (Figs. 5 \& 6C). 


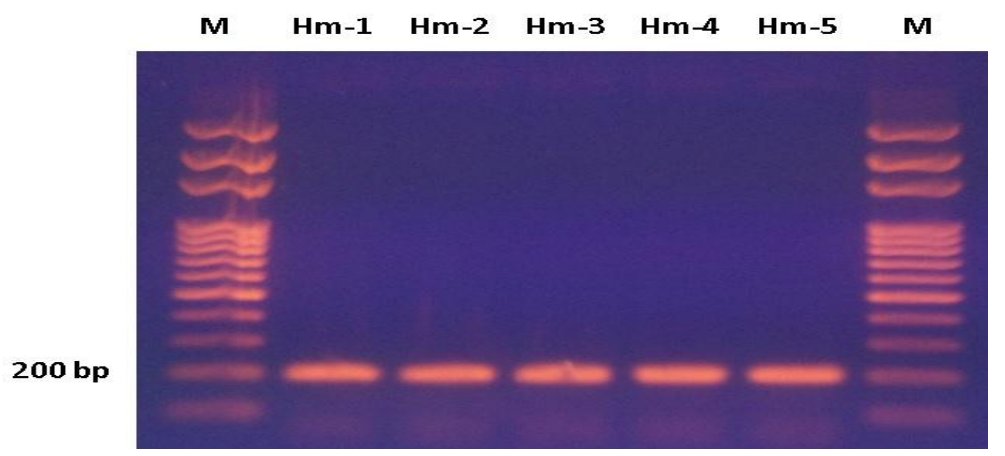

Fig. (1): PCR amplification products obtained with the specific primer of Harpophora maydis to identify the fungal isolates. Lanes: M, 100 bp DNA Ladder (Solis BioDyne); Hm-1, genomic DNA of $\mathrm{H}$. maydis from Gharbia; Hm-2, genomic DNA of $H$. maydis from Kafr El Sheikh; Hm-3, genomic DNA of $H$. maydis from Beheira; Hm-4, genomic DNA of $H$. maydis from Beni Sweif; Hm-5, genomic DNA of $\boldsymbol{H}$. maydis from Minia governorate maize fields.

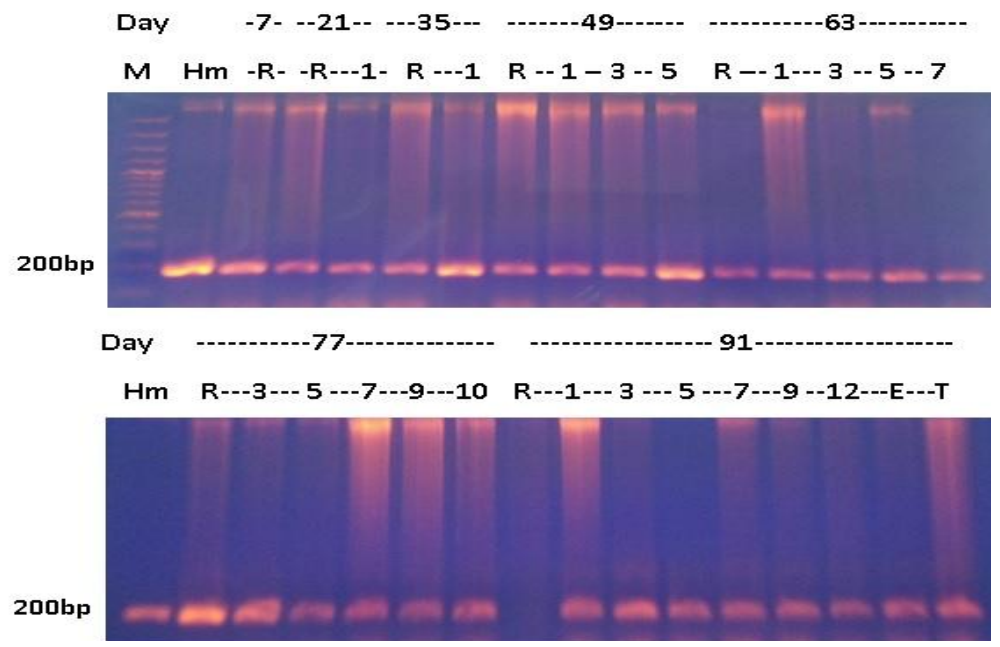

Fig. (2): PCR amplification products obtained with unique Harpophora maydis oligonucleotide to detect the fungus in greenhouse maize plant parts (PIONEER SC3062, 2016) from 7 d post sowing until 91 days. Lanes: $M$, GeneRuler 100 bp Plus DNA Ladder (Thermo Scientific); Hm, genomic DNA of $\boldsymbol{H}$. maydis isolate $\mathrm{Hm}-4$ (Positive control); $\mathrm{R}$, genomic DNA of roots; 1-12: genomic DNA of stalk-internodes from number 1 to 12; $E$, genomic DNA of cob with initiated seeds; $T$, genomic DNA of tassel.

Egypt. J. Phytopathol., Vol. 47, No. 1 (2019) 

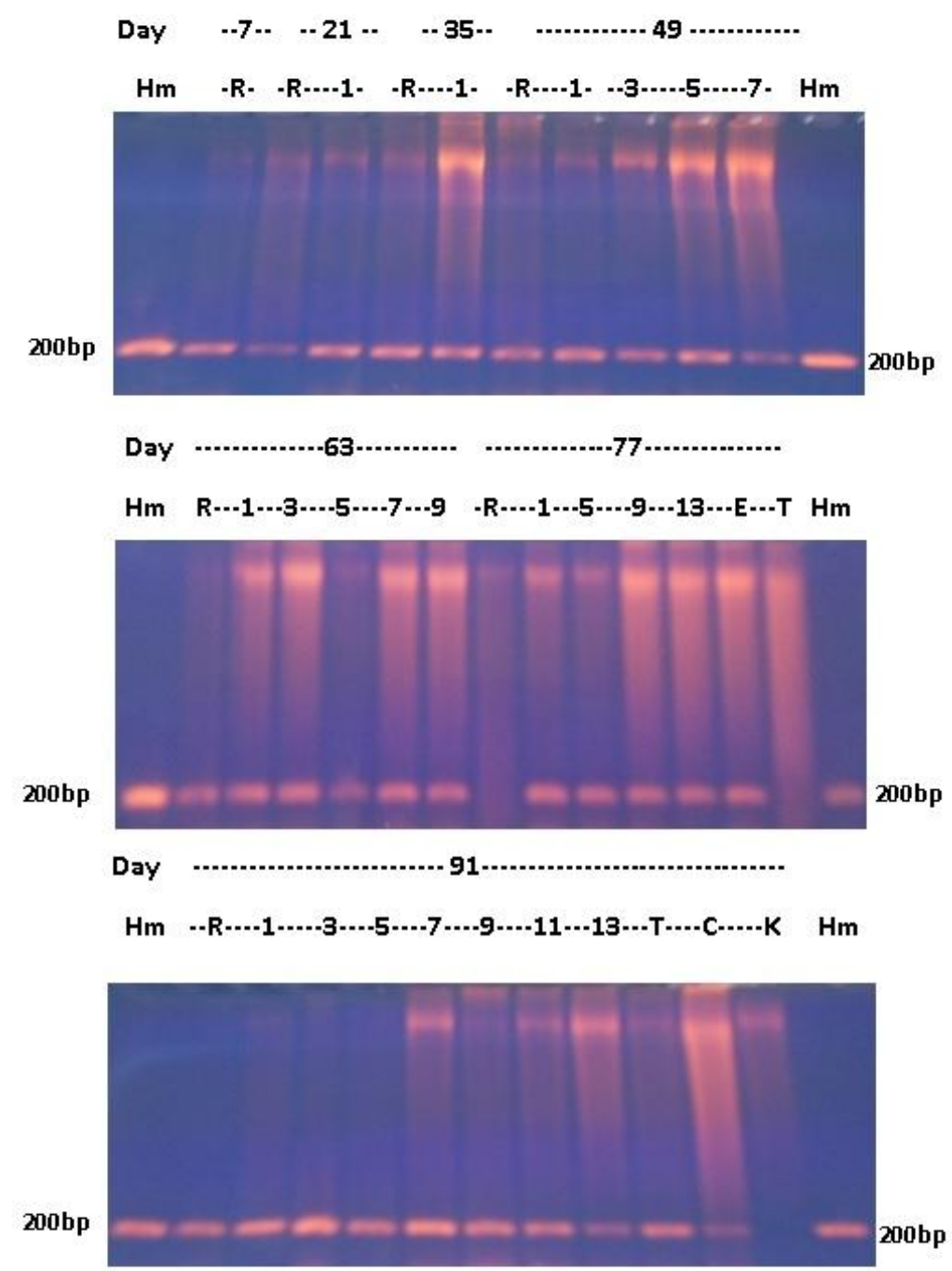

Fig. (3): PCR amplification products obtained with the unique Harpophora maydis oligonucleotide to detect the fungus in greenhouse maize plant parts (PIONEER SC3062, 2017) from $7 \mathrm{~d}$ post sowing until 91 days. Lanes: $\mathrm{Hm}$, genomic DNA of $\boldsymbol{H}$. maydis isolate $\mathrm{Hm}-4$ (Positive control); $\mathrm{R}$, genomic DNA of roots; 1-13: genomic DNA of stalk-internodes from number 1 to 13; $E$, genomic DNA of cob with initial seeds; T, genomic DNA of tassel; C, genomic DNA of cob and $K$, genomic DNA of kernels. 


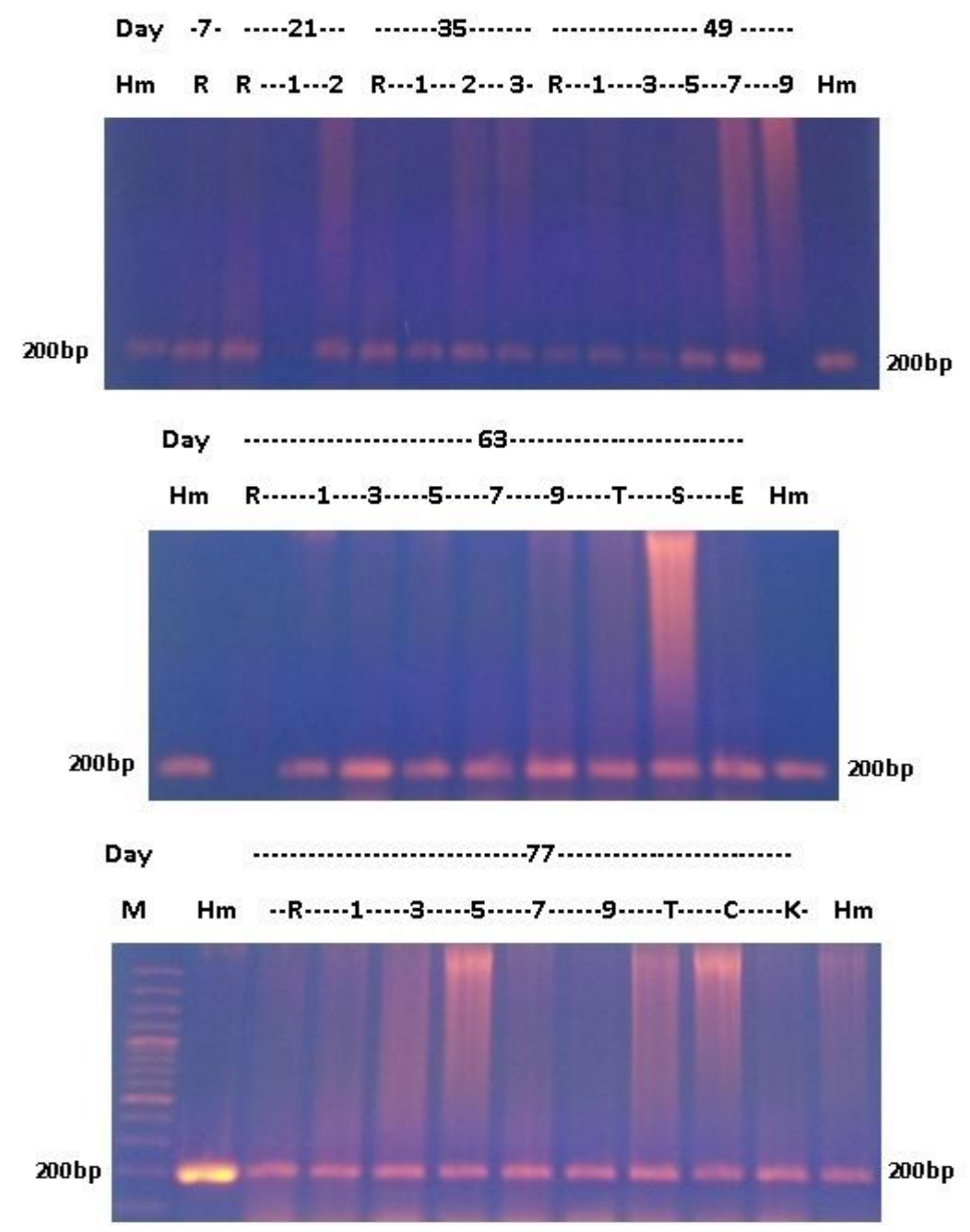

Fig. (4): PCR amplification products obtained with the unique Harpophora maydis oligonucleotide to detect the fungus in field maize plant parts (PIONEER SC3062, 2016) from 7 d post sowing until 77 days. Lanes: M, GeneRuler 100 bp Plus DNA Ladder (Thermo Scientific); Hm, genomic DNA of $\boldsymbol{H}$. maydis isolate $\mathrm{Hm}-4$ (Positive control); $\mathrm{R}$, genomic DNA of roots; 1-9: genomic DNA of stalk-internodes from number 1 to 9; T, genomic DNA of tassel; S, genomic DNA of ear-shank; C, genomic DNA of cob; E, genomic DNA of cob with initial seeds; $K$, genomic DNA of kernels. 

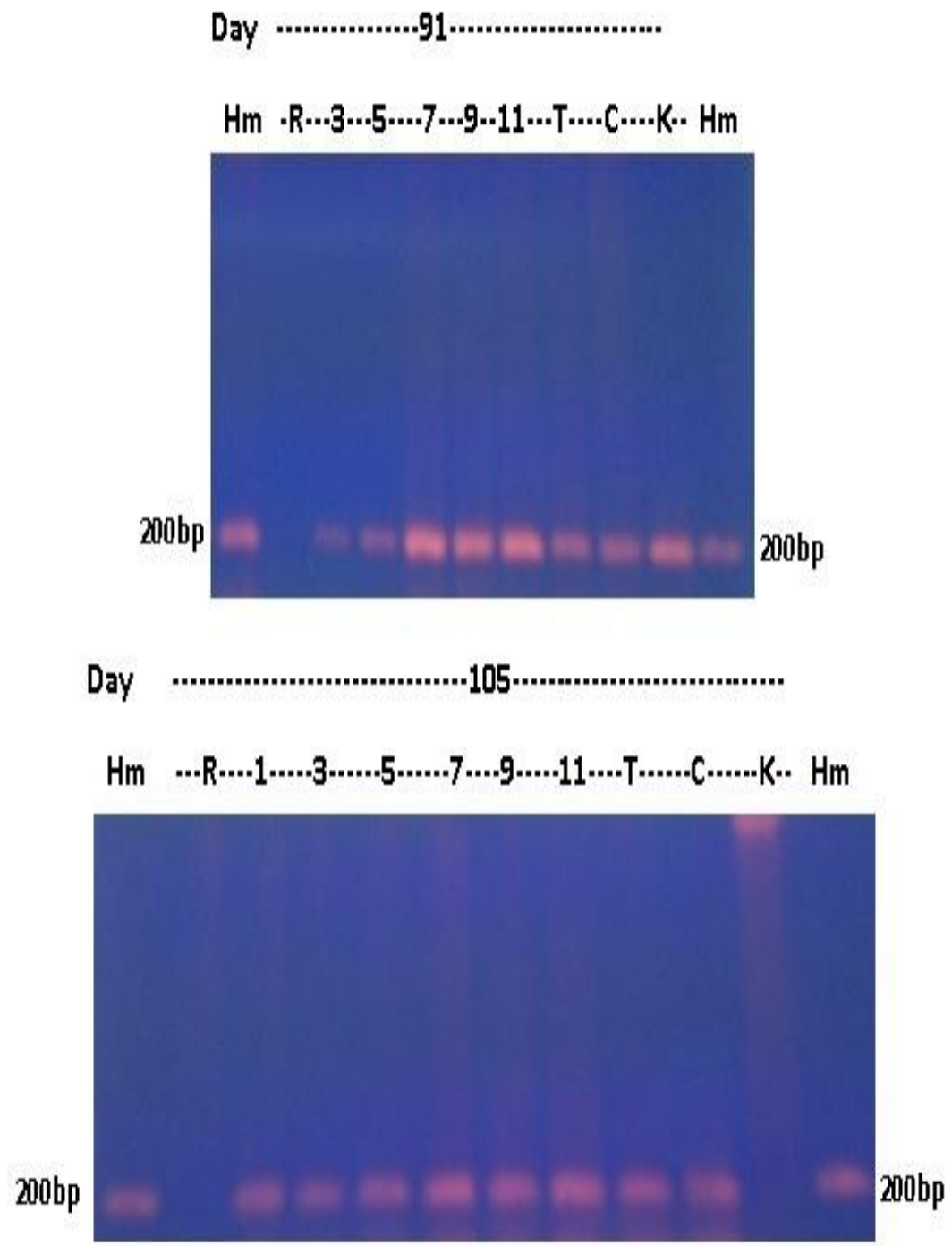

Fig. (5): PCR amplification products obtained with the unique Harpophora maydis oligonucleotide to detect the fungus in field maize plant parts (PIONEER SC3062, 2016) at the age of 91 and 105 days. Lanes: Hm, genomic DNA of $\mathrm{H}$. maydis isolate $\mathrm{Hm}-4$ (Positive control); R, genomic DNA of roots; 1-11: genomic DNA of stalk-internodes from number 1 to 11; T, C and K, genomic DNA of tassels, cobs and kernels, respectively. 

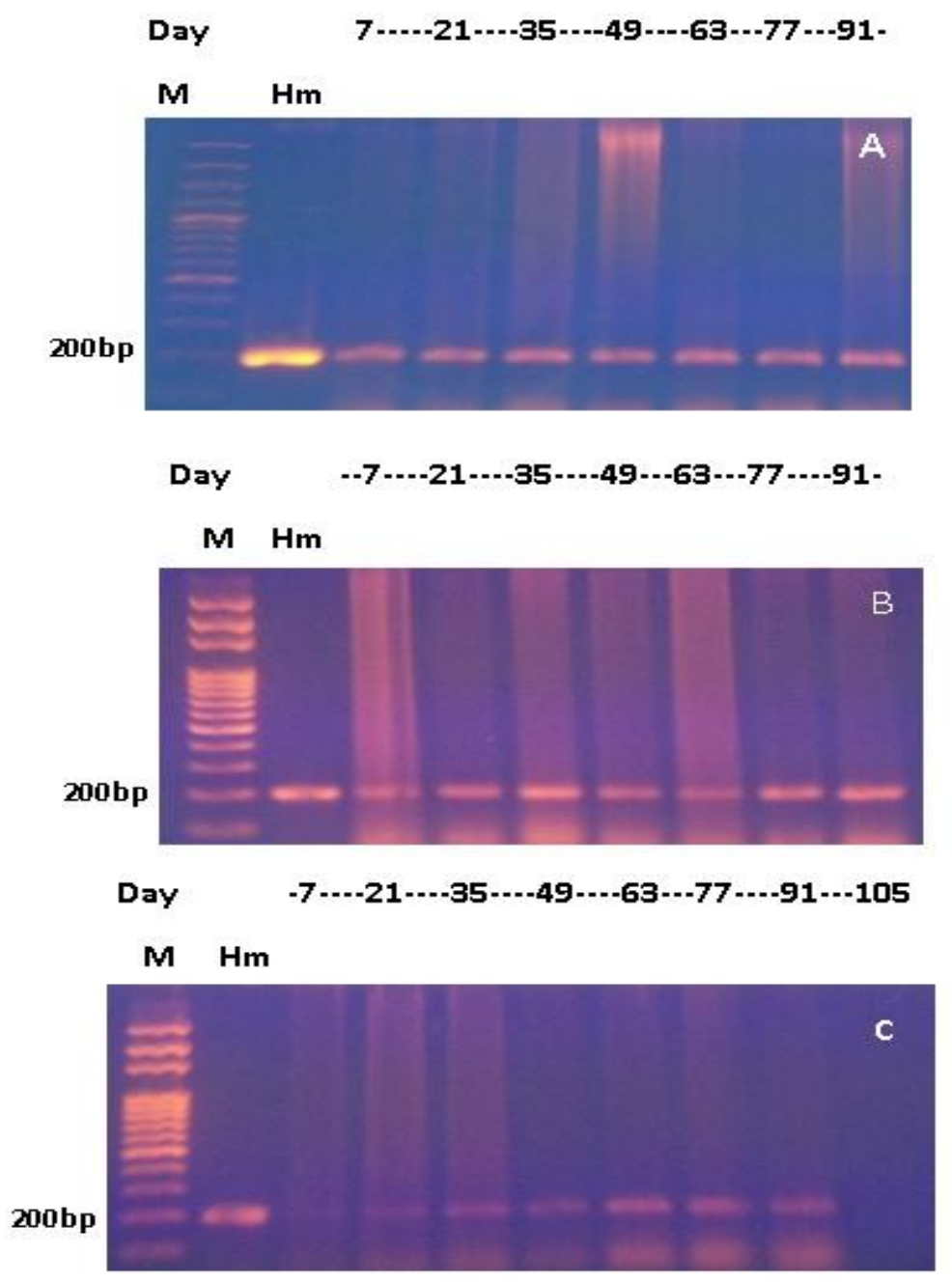

Fig. (6): PCR amplification products obtained with the unique Harpophora maydis oligonucleotide to detect the fungus in maize plant leaves (PIONEER SC3062, 2016) from $7 \mathrm{~d}$ post sowing until $91 \mathrm{~d}$ in the greenhouse (A \& B panels; 2016 and 2017, respectively) and until $105 \mathrm{~d}$ in the field ( $\mathrm{C}$ panel; 2016). Lanes: $M$ in panel $A$, GeneRuler 100 bp Plus DNA Ladder (Thermo Scientific); $M$ in panels B \& C, 100 bp DNA Ladder (Solis BioDyne); Hm, genomic DNA of $\mathrm{H}$. maydis isolate $\mathrm{Hm}-4$ (Positive control). 
Recovery of H. maydis on PDA

The obtained results (Table 2) show that the first recovery of $H$. maydis on PDA was found only in stalk-internode samples taken from greenhouse plants (2016 and 2017) with the age of 63 days. While, at the age of 77 days, the fungus was recovered from root and stalk-internode samples. On the other hand, the fungus was recovered from root, stalk-internode and tassel samples of 91 days old plants. In 2016-field trail, the first recovery of the causal agent of late wilt was appeared in both root and stalk-internode samples taken from plants with the age of 63 and 77 days. Also, the fungus was recovered from root, stalk-internode and tassel samples of both 91 and 105 days old plants. However, the fungus was not recovered from either leaf or kernel samples taken from any plant age.

Table (2): Harpophora maydis-recovery from different maize plant parts with or without symptoms at different plant ages ranged from 7 to 105 days after sowing under greenhouse and field conditions, 2016 and 2017 growing seasons.

\begin{tabular}{|c|c|c|c|c|c|c|c|c|}
\hline \multirow{2}{*}{$\begin{array}{l}\text { Exp. } \\
\text { name }\end{array}$} & \multirow{2}{*}{$\begin{array}{c}\text { Plant } \\
\text { age } \\
\text { /day }\end{array}$} & \multirow[b]{2}{*}{ Symptoms } & \multicolumn{6}{|c|}{ H. maydis-recovery from } \\
\hline & & & Roots & $\begin{array}{c}\text { Stalk } \\
\text { internode }\end{array}$ & Leaves & Tassel & $\mathrm{Cob}$ & Kernel \\
\hline \multirow{7}{*}{ 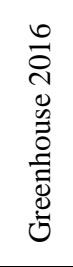 } & 7 & No & -1 & - & - & & & \\
\hline & 21 & No & - & - & - & & & \\
\hline & 35 & No & - & - & - & & & \\
\hline & 49 & No & - & - & - & & & \\
\hline & 63 & Two dried leaves & - & + & - & - & & \\
\hline & 77 & Four dried leaves & +2 & + & - & - & & \\
\hline & 91 & $\begin{array}{c}\text { Five dry leaves with } \\
\text { streaking in stem }\end{array}$ & + & + & - & + & - & \\
\hline \multirow{7}{*}{ 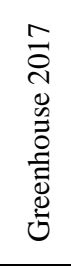 } & 7 & No & - & - & - & & & \\
\hline & 21 & No & - & - & - & & & \\
\hline & 35 & No & - & - & - & & & \\
\hline & 49 & No & - & - & - & & & \\
\hline & 63 & Two dried leaves & - & + & - & - & & \\
\hline & 77 & Three dried leaves & + & + & - & - & & \\
\hline & 91 & $\begin{array}{l}\text { All leaves were dried } \\
\text { with streaking in stem }\end{array}$ & + & + & - & + & - & - \\
\hline \multirow{8}{*}{$\begin{array}{l}0 \\
\frac{0}{0} \\
\frac{0}{0} \\
\frac{0}{1}\end{array}$} & 7 & No & - & - & - & & & \\
\hline & 21 & No & - & - & - & & & \\
\hline & 35 & No & - & - & - & & & \\
\hline & 49 & No & - & - & - & & & \\
\hline & 63 & No & + & + & - & - & & \\
\hline & 77 & five dried leaves & + & + & - & - & - & - \\
\hline & 91 & $\begin{array}{l}\text { All leaves were dried } \\
\text { with streaking in stem }\end{array}$ & + & + & - & + & - & - \\
\hline & 105 & $\begin{array}{l}\text { All leaves were dried } \\
\text { with streaking in stem }\end{array}$ & + & + & - & + & - & - \\
\hline
\end{tabular}

1: H. maydis was not recovered; 2: H. maydis was recovered 


\section{Discussion}

The importance of the late wilt disease in Egypt and in other countries where it has been reported came from the sudden and rapid wilt of maize plants at the time of flowering until shortly before maturity (Sabet et al., 1966 and Payak et al., 1970) and its impact on yield depends on the time of symptoms appearance (El-naggar $e t$ al., 2015). Moreover, in the past late wilt of maize caused by H. maydis has existed in Egypt only (Samra et al., 1962 and 1963) and was remained mostly restricted in this country for eight years. But today, the disease is distributed at other countries such as India, Portgal, Spain, Italy, Hungary and in Israel (Payak et al., 1970; Molinero-Ruiz and Melero-Vara et al., 2011; Pecsi and Nemeth, 1998; Drori et al., 2013 and Ortiz-Bustos et al., 2016). So, the detection of the causal agent before the appearance of plant wilting (especially in early stages of plant age) is useful for managing the disease.

Results of the present investigation revealed that the first detection of the fungal DNA was at $7 \mathrm{~d}$ after seeding in roots and leaves of greenhouse and field seedlings. This means that when the fungus touches with maize roots, its penetration and distribution through the roots and primary leaves tissues required 7days. These results are inconsistent with those obtained by Sabet et al. (1970a); Drori et al. (2013) as well as Degani and Cernica (2014). Sabet et al. (1970a) reported that after the fungus penetrate the plant roots, reached to the root endodermis and the xylem after 15 and 21days of sowing date, respectively. Also, in 2013 Drori et al., used the same specific primer to diagnose the fungus in field sweet corn roots and leaves of 22-78d old plants and they reported that the first detection of the fungus was at 43 days after sowing. Recently, Degani and Cernica (2014) demonstrated that $H$. maydis DNA was clearly identified in roots, stems and leaves of $22 \mathrm{~d}$ old maize seedlings grown in infested soils. Meanwhile, the obtained results revealed that the DNA of the fungus was existed in roots and primary leaves of 7 days old seedlings.

In this study, at the age of $15,35,49,63$ days, the fungus was detected in all emerged plant parts. This result was some consistent with that obtained by Drori et al. (2013), since they could diagnose $H$. maydis in sweet corn roots and stems of plants with the age of 43 days. Also, these results are in agreement with those obtained by Sabet et al. (1970a) who reported that after 21 days of sowing, the hyphae of the pathogen were almost confined to upwards growth in the vessels, and finally reached vessels of the fourth internode above ground at the age of 7 weeks. Furthermore, with pathogen progression, from $77 \mathrm{~d}$ to $91 \mathrm{~d}$. after sowing, the obtained results showed that the fungal DNA was clearly detected in all tested stalkinternodes, tassels, ear-shanks, cobs, kernels and leaves consistently with symptoms appearance. These results are consistent with the fact that the causal agent of late wilt is vascular pathogen as well as seed transmitted (Samra et al., 1966; El-Shafey et al., 1991; Michail et al., 1999 and Drori et al., 2013).

Egypt. J. Phytopathol., Vol. 47, No. 1 (2019) 
In this research, the author could not detect the pathogen in mature kernels (at $105 \mathrm{~d}$ after planting) sampled from a plant existed positive detection of pathogen DNA in other tested parts even the cob. Indeed, this may be due to: the fungus did not reach to the kernels, or the fungus entered in dormancy stage with very little amount of DNA unable to detect, or the high levels of polysaccharides frequently present in kernels which significantly affect the efficiency of DNA extraction, and/or due to the presence of PCR inhibitors that can negatively impact on successful amplification of the recovered DNA (De Boer et al., 1995; Hu et al., 1999 and Murillo et al., 1998). So, further attempts are needed to adapt method for H. maydis detection or diagnosis in mature or commercial maize seeds.

Furthermore, the obtained results showed that the PCR based method is more efficient for the pathogen detection than that of traditional method. These results have matched with the nature of weak competitive saprophytic ability of $H$. maydis with the other stalk rot pathogens attack maize plants (Sabet et al., 1970b).

In this study, the PCR based assay using H. maydis specific primer, (Saleh and Leslie, 2004) which developed by Drori et al. (2013), was successfully suitable to detect the causal agent of late wilt in different maize plant parts in relation to the plant age; providing more information about the movement of the fungus in maize from sowing to maturity with clear vision of the causal organism disease cycle. On the other hand, early detection of the fungus in leaves, from 7 to $50 \mathrm{~d}$ after sowing, may help researchers and maize breeders to test the plants for $H$. maydis colonization without cutting any plant, hence restrict disease spread (Samra et al., 1966; El-shafey et al., 1991 and Michail et al., 1999). Moreover, early detection of the causal agent may help to apply, agro-mechanic techniques such as intensive watering (Samra et al., 1966), and possibly other treatments to reduce late wilt such as phosphorus, organic amendments, micronutrients $(\mathrm{Cu}, \mathrm{Fe}, \mathrm{Mn}$, and $\mathrm{Zn})$ and chemical control (Singh and Siradhana, 1990 and Degani et. al., 2018). As well as, the detection of the pathogen in leaves at any plant age may help to test the effect of available control methods on $H$. maydis movement inside maize plants (Degani and Cernica, 2014). Eventually, this PCR analysis was successfully employed to identify $H$. maydis directly from the mycelia that embedded in maize plant parts, with no need to obtain pure fungal cultures for diagnosis. Thus, this protocol can be used for diagnosis of infected plants (Mbofung and Pryor 2010 and Lee et al., 2001) by late wilt causal agent.

\section{References}

Allen,G.C.; Flores-Vergara, M.A.; Krasynanski, S.; Kumar, S. and Thompson, W.F. 2006. A modified protocol for rapid DNA isolation from plant tissues using cetyltrimethylammonium bromide. Nature Protocols, 1(5): 2320-2325. 
Drori, R.; Sharon, A.; Goldberg, D.; Rabinovitz, O.; Levy, M. and Degani, O. 2013. Molecular diagnosis for Harpophora maydis, the cause of maize late wilt in Israel. Phytopathologia Mediterranea, 52(1): 16-29.

DeBoer, S.H.; Ward, L.J.; Li, X. and Chittaranjan, S. 1995. Attenuation of PCR inhibition in the presence of plant compounds by addition of BLOTTO. Nuclic Acids Res., 23: 2567-2568.

Degani, O. and Cernica, G. 2014. Diagnosis and control of Harpophora maydis, the cause of late wilt in maize. Advances in Microbiol., 4: 94-105.

Degani, O.; Dor, S.; Movshowitz, D.; Fraidman, E.; Rabinovitz, O. and Graph, S. 2018. Effective chemical protection against the maize late wilt causal agent, Harpophora maydis, in the field. PlosOne, 13(12): e0208353.

El-Gazzar N.; EL-bakery A.M.; Ata A.A. 2018. Influence of some bioagents and chitosan nanoparticles on controlling maize late wilt and improving plants characteristics. Egypt. J. Phytopathol., 46(2): 243-264.

El-Naggar, A.A.A., and Sabry, A.M. 2011. Asymptomatic infection of maize late wilt caused by Cephalosporium maydis. J. Plant Prot. and Path., Mansoura Univ., 2(12): 1081-1087.

El-Naggar, A.A.A.; Sabry, A.M. and Yassin, M.A. 2015. Impact of late wilt disease caused by Harpophora maydis on maize yield. J. of Biol. Chem. Environ. Sci., Ain-Shams Univ., 10(3): 577-595.

El-Shafey, H.A.; Ibrahim, T.F.; Zein El-Abedeen, A. and El-Morsy, G.A. 1991. A technique for isolating Cephalosporium maydis from maize grains. Fourth Arab Congress of Plant Protection 1-5 Dec, Cairo. 155-161.

El-Shabrawy, E.M. and Shehata, H.S. 2018. Controlling maize late-wilt and enhancing plant salinity tolerance by some rhizobacterial strains. Egypt. J. Phytopathol., 46(1): 235-255.

El-Shafey, H.A. and Claflin, L.E. 1999. Late wilt. Pp.43-44. In: D. G. White (ed) Compendium of corn Diseases, $3^{\text {rd }}$ ed. ABS Press, St. Paul, MN. 78pp.

El-Shehawy, A.E.A.; Ata, A.A. and El-Ghonemy, M.A.M. 2014. Impact of late wilt caused by Cephalosporium maydis on maize grain yield and protein content. Egypt. J. of Phytopathol., 42(1): 1-10.

Gams, W. 2000. Phialophora and some similar morphologically little-differentiated anamorphs of divergent ascomycetes. Studies in Mycology, 45: 187-199.

Hu, X.; Nazar, R.N. and Robb, J. 1999. Quantification of Verticillium biomass in wilt disease development. Physiol. Mol. Plant Pathol., 42: 23-36.

Egypt. J. Phytopathol., Vol. 47, No. 1 (2019) 
Johal, L.; Huber, D.M. and Martyn, R. 2004. Late wilt of corn (maize) pathway analysis: international introduction of Cephalosporium maydis. In: Pathways analysis for the introduction to U.S. of plant pathogens of economic importance. U.S. Department of Agriculture, Animal and Plant Health Inspection Service. Technical report no. 503025.

Lee, H.K.; Tewari, J.P. and Turkinton, T.K. 2001. A PCR assay to detect Rhynchosporium secalis in barly seed. Plant Dis., 85: 220-225.

Mbofung, G.C.Y. and Pryor, B.M. 2010. A PCR-based assay for detection of Fusarium oxysporum f. sp. lactucae in lettuce seed. Plant Dis. 94: 860-866.

Michail, S.H.; Abou-Elseoud, M.S. and Eldin, M.S.N. 1999. Seed health testing of corn for Cephalosporium maydis. Acta-Phytopathologica-etentomologicaHangarica, 34: 35-41.

Molinero-Ruiz, M.L.; Melero-Vara, J.M. and Mateos, A. 2011. Cephalosporium maydis, the cause of late wilt in maize, a pathogen new to Portugal and Spain. Plant Dis., 94: 379.

Moller, M.E.; Chelkowski, J and Geiger, H.H. 1999. Species-specific PCR assays for the fungal pathogens Fusarium moniliforme and Fusarium subglutinans and their application to diagnose maize ear rot. J. Phytopathology., 147: 497-508.

Murillo, I.; Cavallarin, L. and San Segundo, B. 1998. The development of a rapid PCR assay for detection of Fusarium moniliforme. European J. of Plant Pathol., 104: 301-311.

Nicholson, P.; Lees A.K.; Maurin, N.; Parry, D.W. and Rezanoor, H.N. 1996. Development of a PCR assay to identify and quantify Microdochium nivale var nivale and Microdochium nivale var majus in wheat. Physiol. Mol. Plant Pathol., 48: 257-271.

Ortiz-Bustos, C.M.; Testi, L.; Garcia-Carneros, A. B. and Molinero-Ruiz, L. 2016. Geographic distribution and aggressiveness of Harpophora maydis in the Iberian Peninsula, and thermal detection of maize late wilt. Eur. J. Plant Pathol., 144: 383-397.

Payak, M.M.; Lal, S.; Lilaramani, J. and Renfro, B.L. 1970. Cephalosporium maydis-a new threat to maize in India. Indian Phytopathology, 23: 562-569.

Pecsi, S. and Nemeth, L. 1998. Appearance of Cephalosporium maydis Samra, Sabet and Hingorani in Hungary. Mededelingen Faculteit Landbouwkundige en Toegepaste Biologische Wetenschappen, Universiteit Gent. 63: 873-877.

Sabet, K.A.; Samra, A.S. and Mansour, IM. 1966. Late wilt disease of maize and a study of the causal organism in U.A.R. pp 8-45. In: Samra,A.S. and Sabet, K.A., Abdel Rahim, M.F., El Shafey, H.A., Mansour, I.M., Fadl, F.A., Dawood Nadia 
A. and Khalil Ikbal, H.I. Investigations on stalk rot diseases of maize in U.A.R. Minstry of Agriculture, Government Printing Offices, Cairo, Egypt.

Sabet, K.A.; Zaher, A.M.; Samra, A.S. and Mamsour, I.M. 1970a. Pathogenic behavior of Cephalosporium maydis and C. acremonium. Ann. Appl. Biol., 66: 257-263.

Sabet, K.A.; Samra, A.S. and Mamsour, I.M. 1970b. Saprophytic behavior of Cephalosporium maydis and C. acremonium. Ann. Appl. Biol., 66: 265-271.

Saleh, A.A. and Leslie, J.F. 2004. Cphalosporium maydis is a distinct species in Gaeumannomyces-Harpophora species complex. Mycologia., 96: 1294-1305.

Samra, A.S.; Sabet, K.A. and Hingorani, M.K. 1962. A new wilt disease of maize in Egypt. Plant. Dis. Reptr., 46: 481-483.

Samra, A.S.; Sabet, K.A. and Hingorani, M.K. 1963. Late wilt disease of maize caused by Cephalosporium maydis. Phytopath., 53: 402-406.

Samra, A.S.; Sabet, K.A. and Abdel-Rahim, M.F. 1966. Seed transmission of stalkrot fungi and effect of seed treatment. pp 94-116. In: Samra, A.S. and Sabet, K.A., Abdel Rahim, M.F., El Shafey, H.A., Mansour, I.M., Fadl, F.A., Dawood Nadia A. and Khalil Ikbal, H.I. Investigations on stalk rot diseases of maize in U.A.R. Ministry of Agriculture, Government Printing Offices, Cairo, Egypt.

Singh, S.D., and Siradhana, B.S. 1990. Effect of macro and micronutrients on the development of late wilt of maize induced by Cephalosporium maydis. Summa Phytopathology. 16: 140-145.

Steel, R.G.D. and Torrie, J.H. 1980. Principles and Procedures of Statistics. McGraw Hill Book Company Inc., New York, 481p.

Corresponding author: El-Naggar, A.A.A.

E-mail: elnaggar06@gmail.com

(Received 14/04/2019;

in revised form 28/04/2019)

Egypt. J. Phytopathol., Vol. 47, No. 1 (2019) 


\section{الكشف عن الفظر Harpophora maydis لمرض الأبول المتأخر في أجزاء نباتات الذارة الذرة الشامية

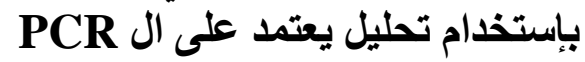 عبدالله أحمد علي النجار

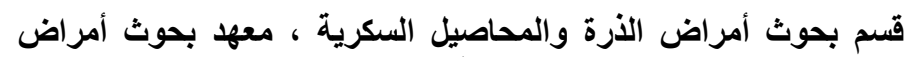

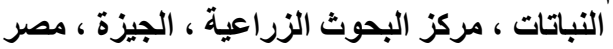

تأتي أهمية مرض الذبول المتأخر في الذرة الثامية المتسبب عن الفطر

Harpophora maydis (Cephalosporium maydis Smra, (Sabet \& Hingorani

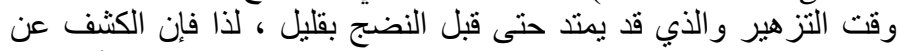

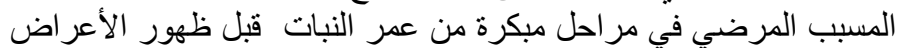

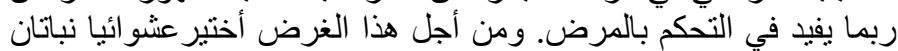

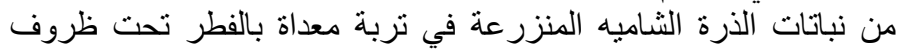

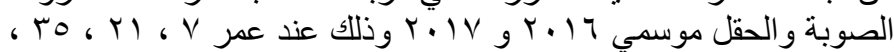
Q الور اثثية للفطر في كل أجزاء النبات المتكثفة بإنتخدام البريمر (بادى النهاء)

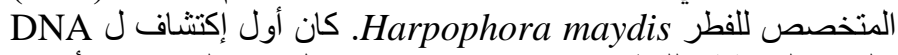

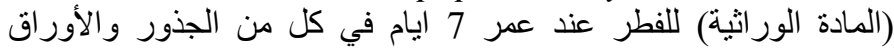

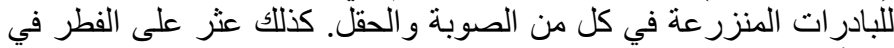

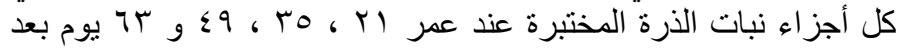

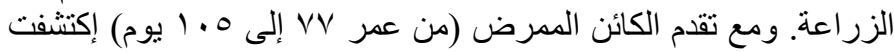

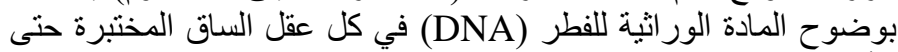

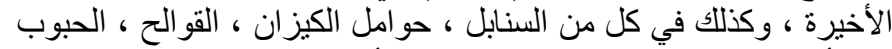

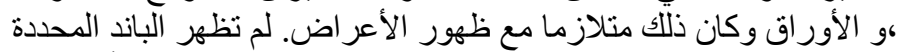

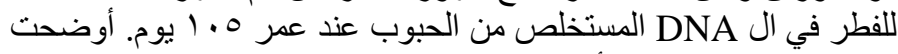

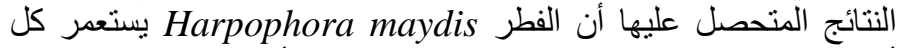

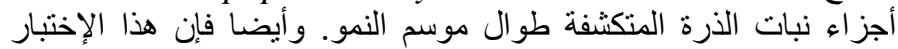

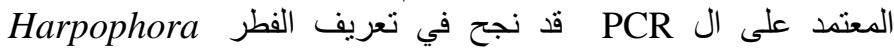

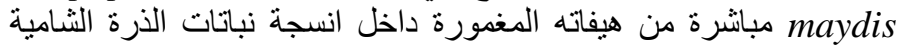

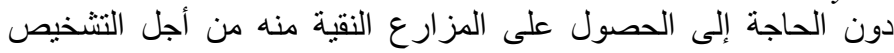

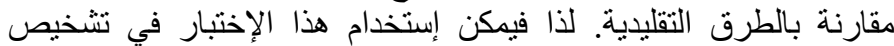
النباتات المصابة بالفطر المسببة لمرض الذبكن الذبول المتأخر. 